\title{
AFFILIATION, INTEGRATION, AND INFORMATION: OWNERSHIP INCENTIVES AND INDUSTRY STRUCTURE*
}

\author{
Thomas N. HubBard $\dagger$
}

\begin{abstract}
This paper presents theory and evidence on horizontal industry structure. At issue is the question: what makes industries necessarily fragmented? The theoretical model examines trade-offs associated with affiliation and integration, and how they are affected by the contracting environment. I show how contractual incompleteness can lead industries to be necessarily fragmented. I also show that contractual improvements will tend to lead to a greater concentration of brands, but whether they lead industries to be more or less concentrated depends on what becomes contractible. I then discuss the propositions generated by the model through a series of case study examples.
\end{abstract}

\section{INTRODUCTION}

TWO CORE THEORETICAL LITERATURES underlie much of the field of industrial organization: theories of industry structure and theories of the firm. Although the issues these literatures emphasize are very different, they actually seek to explain the same thing. Theories of industry structure are, in a way, also theories of firms' boundaries. Likewise, theories of firms' boundaries can also be read as theories of industry structure.

These literatures have different strengths and weaknesses. The industry structure literature provides several good explanations for why industries might be necessarily concentrated. The traditional literature (Bain [1956], Scherer [1980]) emphasizes factors such as scale economies, market size, and entry barriers; the newer literature adds concepts such as heterogeneity in tastes, the strength of price competition, and consumers' sensitivity to sunk expenditures such as advertising (Spence [1976], Dixit and Stiglitz [1977], Salop [1979], Sutton [1991]). But most industries are fragmented — most of their output is produced by small, independently-owned firms - particularly those in the service and retail sectors. ${ }^{1}$ As I describe in more detail

*This research benefitted from conversations with George Baker, Wouter Dessein, Luis Garicano, Rob Gertner, and Bill Vogt and comments from two anonymous referees and an editor. I am grateful for the assistance of Ryan Taliaferro. All remaining errors are mine.

$\dagger$ Author's affiliation: Graduate School of Business, The University of Chicago, Chicago, Illinois, 60637, U.S.A.

e-mail:thomas.hubbard@gsb.uchicago.edu

\footnotetext{
${ }^{1}$ For example, the 1992 Economic Census reports that single-establishment firms make up more than half of revenue in the service sector of the U.S. economy, and the average firm in the 
below, the industry structure literature provides less convincing explanations for why industries or industry segments might be necessarily fragmented. For example, while commonly-owned chains-groups of establishments that are owned by the same entity - such as Home Depot have come to dominate some retail segments in U.S., many segments in retail continue to be served primarily by independently owned stores. Why? Scale economies and the value of brands do not provide a complete explanation, since groups of independently owned establishments can often exploit these through contractual arrangements; the Ace Hardware cooperative and some franchise chains serve as examples. ${ }^{2}$

Recent theories of the firm such as Grossman and Hart [1986] explicitly address the costs and benefits of independent versus common ownership of assets and provide explanations of fragmentation - why establishments might be necessarily independently owned. These and other theories also suggest how ownership related trade-offs might be related to the contracting environment. But directly applying existing models to examine horizontal integration-common ownership of establishments within the same industry - abstracts from an important feature in such contexts. These models assume that trade between establishment managers is efficient, and therefore do not consider the issue of whether it is optimal for the establishments to operate completely independently of one another. It is particularly important in horizontal contexts to allow for this possibility because many establishments have no ties or affiliations with other establishments in their industry. Furthermore, ownership and affiliation trade-offs are likely interrelated: if contractual incompleteness reduces the gains from trade between managers, it can make affiliation inefficient relative to operating completely independently. Thus, analyzing affiliation and ownership trade-offs jointly expands the set of organizational options to include independent operation, and provides a more complete picture of the forces that affect horizontal industry structure.

This paper presents theory and evidence on horizontal industry structure, focusing on situations where plant-level scale economies are small and market power is not an issue.

I first present a canonical model that uses Grossman and Hart [1986] as a foundation, but relaxes the assumption that there are gains from trade between managers and extends the framework by allowing managerial effort to be contractible to varying degrees. In this model, a manager develops a

service sector consists of 1.1 establishments. It also reports that the average retail firm consists of 1.4 establishments, and only $65 \%$ of sales are in multiestablishment firms, despite the presence of several large, highly-concentrated segments such as discount retailing. (Bureau of the Census [1995a,b])

${ }^{2}$ The definition of ownership I use in this paper implies that franchise outlets are independently owned only when franchisees hold residual control rights over their establishment. Franchisees do not always do so.

(C) Blackwell Publishing Ltd. 2004. 
business format that may be valuable if used at establishments other than that at which he works. There are two issues: whether the business format should be used at other establishments, and whether the manager who developed the business format should own the establishments at which it is used. The model distinguishes between the common use of business formats (affiliation) and common ownership (integration), and therefore conceptually distinguishes the concentration of brands and firms in an industry. The model's output is a series of comparative static predictions that relate the concentration of brands and firms to characteristics of establishment managers' jobs and the richness of the contracting environment. The latter is particularly important for applied research because variation in the contracting environment is sometimes observable to researchers-for example, when it corresponds to technological adoption or changes in the legal environment. ${ }^{3}$ A central theme is that improvements in the contracting environment tend to lead to a greater concentration of brands, but whether they lead industries to be more or less concentrated depends on what becomes contractible.

I then discuss the predictions of the model through a series of extended case study examples. Some of these examples come from existing quantitative research; others are newer and less quantitative. These examples show how the various trade-offs in the model are played out in the real world. Future research will test the model's predictions using systematic data.

The rest of the paper is organized as follows. Section 2 briefly motivates the analysis by discussing the shortcomings of the existing industry structure literature. Section 3 presents the model. I first discuss a version where, as in the 'property rights' literature, agents' actions are completely noncontractible. I then present an extension that allows for varying degrees of contractibility; this extension is important because it generates comparative statics with respect to changes in the informational environment. Section 4 discusses the model and presents the case study evidence. Section 5 concludes.

\section{TWO USUAL SUSPECTS}

Scale economies and the value of brands play important roles in the existing literature on industry structure, which focuses on the question: what factors lead industries to be concentrated? These factors, however, do not by themselves determine whether industries are fragmented.

\footnotetext{
${ }^{3}$ See Baker and Hubbard [2001] for an extended discussion of how variation in the contracting environment can help empirical researchers illuminate the determinants of firms' boundaries.
} 
While the presence of large scale economies implies that industries will be concentrated, the converse does not hold: the absence of scale economies does not imply that industries will be necessarily fragmented. Standard replication arguments imply that such industries could either be concentrated or fragmented. Most existing theories of industry structure have neoclassical theories of the firm at their core, and the weaknesses of the neoclassical theories are exposed when trying to explain fragmentation.

To see this, consider an industry where the production technology does not imply significant scale economies - say, dry cleaning. Scale economies are very weak at the retail establishment level in dry cleaning. There is little or no cost disadvantage from operating a small dry cleaning outlet rather than a large one. This partly explains why most dry cleaning outlets are small. Furthermore, it is unlikely that there are scale economies from operating multiple outlets rather than single ones. ${ }^{4}$ However, the absence of such economies does not explain why the dry cleaning business is so fragmented. While there may be no cost advantage from operating multiple outlets, this argument does not imply a disadvantage - the absence of scale economies does not imply that there exist scale diseconomies. Absent other factors, the industry could consist either of a few large chains of commonlyowned outlets or of many independent outlets. Since one objective of the analysis is to identify forces that cause fragmentation, production scale economies will take a back seat in the analysis.

The second usual suspect is the value of brands. The main point here is that consumers' brand or advertising sensitivity may lead industries to be concentrated in terms of brands, but brand concentration does not necessarily imply firm concentration because brands can be produced by multiple firms. In this light, Sutton's [1991] seminal work on industry structure speaks at least as much to the concentration of brands, or business formats, in an industry as to the concentration of firms.

This point is perhaps clearest in the context of chains. Starbucks and Ace Hardware are both chains: each has many affiliated establishments that share the same brand name and basic business format. Starbucks and Ace differ in an important way, however. Almost all Starbucks outlets are owned by Starbucks Corporation. ${ }^{5}$ Nearly all Ace outlets are independently owned. Affiliation is valuable both in coffee and hardware retailing, but this fact alone does not necessarily imply that establishments that share business formats or brand names will be commonly-owned - and thus whether these industries will consist of few or many firms.

\footnotetext{
${ }^{4}$ Scale economies may be greater upstream, for example from operating a dry cleaning plant that serves multiple retail outlets.

${ }^{5}$ One important exception is in airports, where existing agreements between concessionaires and airport authorities make it hard for Starbucks to own these outlets.
}

(C) Blackwell Publishing Ltd. 2004. 
Reflecting on the hardware example for a bit is worthwhile, because the organizational alternatives in the model below are familiar in this context. Some hardware sellers are completely independent; they are owned by their manager and are not affiliated with other establishments. Some, like Ace affiliates, are part of independently owned chains: they are owned by their manager and share a brand name with other outlets. ${ }^{6}$ Some, like Home Depot stores, are part of commonly-owned chains. They are affiliated with other outlets but are not owned by their manager.

The fact that all three organizational forms appear in hardware retailing is somewhat unusual, but the point that three broad alternatives exist for an establishment is a general one. In general, establishments may or may not share a business format and those that share formats may or may not be owned by the same party. Note that I am using the phrase 'business format' broadly, to refer to many potential sources of affiliation in addition to business practices, brand names, and trademarks. In some manufacturing contexts a business format may center around a proprietary technology; affiliations occur when multiple establishments use this technology, and therefore may be enabled by licensing arrangements. In certain retailing contexts, a business format may be a set of purchasing or advertising arrangements, and affiliations may provide for collective purchasing or advertising.

The next section presents a model for understanding when and why establishments have common formats and/or ownership. ${ }^{7}$ While the model is cast in terms of an industry that produces a single, undifferentiated product or service, it can be applied more narrowly to industry segments in contexts where intra-industry product differentiation is important. ${ }^{8}$ Industries, or industry segments, in which factors strongly favor independent ownership of establishments are necessarily fragmented.

\section{THE MODEL}

Suppose an industry consists of a large number of establishments, each of which is run by an individual manager. Denote two of these establishments as A1 and A2; these are run by managers Victor and Paul, respectively. Suppose Victor develops a business format that raises the value of any individual establishment by $\mathrm{K}$. He puts this in place at his establishment,

\footnotetext{
${ }^{6}$ In other contexts such as fast food, franchise outlets fall in this category when the franchisee owns the establishment. I discuss this further below. See also Maness [1996].

${ }^{7}$ This model extends that in Baker and Hubbard [2002], which in turn adapts Grossman and Hart [1986] to a context where individuals make multidimensional effort decisions and ownership creates good and bad incentives in the same individual.

${ }^{8}$ In fact, several of the case examples below will use the model to understand cross-segment differences in industry structure.
} 
A1. ${ }^{9}$ This business format is a source of increasing returns, which could in principle be exploited by groups of independently or commonly-owned establishments. From the perspective of other establishments, this business format can represent many potential sources of value from affiliating with A1 depending on the context, including brand names, proprietary technologies, or purchasing arrangements.

The model investigates two questions. First, under what conditions should Victor's business format be used at A2 as well? That is, should A2 be part of a chain ('Victor's') or not? Second, who should own A2: Victor or Paul? In particular, if A 1 and $\mathrm{A} 2$ are part of a chain, should this chain consist of independently or commonly-owned establishments?

\section{III(i). A2's Value and Paul's Decisions}

I first specify A2's value under different business formats. Let V be A2's value if Victor's business format is used. Specify V as:

$$
V=K+\sum_{i=1}^{g_{1}} e_{1}^{i}
$$

Let $\mathrm{P}$ be A2's value if Paul's format is used. Specify $\mathrm{P}$ as:

$$
P=\sum_{i=1}^{g_{2}} e_{2}^{i}+\sum_{i=1}^{g_{1}} e_{1}^{i}
$$

Paul affects $\mathrm{V}$ and $\mathrm{P}$ through two classes of effort decisions. These are represented by vectors $\mathrm{e}_{1}=\left\{\mathrm{e}_{1}^{\mathrm{i}}\right\}$ and $\mathrm{e}_{2}=\left\{\mathrm{e}_{2}^{\mathrm{i}}\right\}$, which have dimensions $\mathrm{g}_{1}$ and $\mathrm{g}_{2}$, respectively.

The vector $\mathrm{e}_{1}$ consists of actions that increase A2's value, regardless of whose business format is used. (Note that $\mathrm{e}_{1}$ enters the expressions for $\mathrm{V}$ and $P$ in the same way.) I will refer to activities in $e_{1}$ as 'establishment management,' or simply 'management.' Among other things, $\mathrm{e}_{1}$ could include actions that enhance the establishment's reputation with its customers - a reputation for a clean store or friendly service might increase a store's value regardless of its business format. This interpretation would be particularly salient in service or retail contexts. This is not the only possible interpretation, however. It could also include actions that maintain the value of physical plant, or cost-reducing innovations that have industry-wide value. For simplicity, I assume that the individual actions $e_{1}^{i}$ have equal

\footnotetext{
${ }^{9}$ Alternatively, one could assume that the owner of the business format does not own any establishments, and little would change. I present the model as a two-asset, two-manager model because it links the analysis to Grossman and Hart [1986] and reinforces the horizontal integration and industry structure themes in the introduction. It also captures something real: business formats are often developed by entrepreneurs who use it first at an establishment they own, then consider extending it to other outlets.
} 
marginal productivity, and normalize this marginal productivity to one. Each of these actions represent a distinct opportunity to affect A2's value.

The dimension of $\mathrm{e}_{1}$ is $\mathrm{g}_{1}$. The higher $\mathrm{g}_{1}$, the more opportunities Paul has to affect A2's value. Following from above, $g_{1}$ will tend to be high when A2's value is reputation-sensitive, when managerial actions are important for maintaining physical assets' value, or when managers are important sources of industry-wide innovations.

The vector $e_{2}$ consists of actions that increase A2's value if Paul's business format is used, but not if Victor's is used. (Note that $\mathrm{e}_{2}$ enters the expression for $\mathrm{P}$ but not $\mathrm{V}$.) Therefore $\mathrm{e}_{2}$ includes activities such as generating alternative business formats for A2, lining up clients for such formats, and producing process or product innovations that are incompatible with Victor's format. These are activities that would be considered entrepreneurial conditional on Paul's format being used, but opportunistic conditional on Victor's. This captures the idea that entrepreneurial and opportunistic activities are often differentiated by their context rather than their substance. ${ }^{10}$ I will henceforth refer to $e_{2}$ as Paul's 'entrepreneurial activities' with the understanding that such activities may or may not be desirable.

The dimension of $\mathrm{e}_{2}$ is $\mathrm{g}_{2}$. If $\mathrm{g}_{2}$ is low, Paul has few opportunities to engage in entrepreneurial activities. This would be the case when managers' efforts toward developing business formats are unlikely to be productive. This may be true if A2 were a large discount retailing outlet (a Wal-Mart), for example. If $\mathrm{g}_{2}$ is high, Paul has many opportunities to do things that increase A2's value but are incompatible with other establishments' format. This might be the case if A2 were a high-end restaurant at which chefs encounter opportunities to create special dishes when seasonal food becomes available locally; such specials would be incompatible with restaurant formats that emphasize cross-outlet uniformity. As above, I assume that the individual actions $\mathrm{e}_{2}^{\mathrm{i}}$ have equal, unitary marginal productivity.

I assume that effort is costly to Paul, and these costs are represented by the equation:

$$
C=\sum_{i=1}^{g_{1}} \frac{1}{2}\left(e_{1}^{i}\right)^{2}+\sum_{i=1}^{g_{2}} \frac{1}{2}\left(e_{2}^{i}\right)^{2}
$$

Costs are thus convex in $\mathrm{e}_{1}^{\mathrm{i}}$ and $\mathrm{e}_{2}^{\mathrm{i}}$, and $\mathrm{e}_{1}^{\mathrm{i}}$ and $\mathrm{e}_{2}^{\mathrm{i}}$ are neither complements nor substitutes in Paul's effort supply function. This assumption makes choices of $e_{1}^{i}$ and $e_{2}^{i}$ independent of each other. This corresponds to a situation where Paul faces a series of independent opportunities to affect A2's value. Independence means that, unlike in Holmstrom and Milgrom [1991, 1994], managers do not face meaningful effort allocation decisions. This will be

\footnotetext{
${ }^{10}$ This is noted by Holmstrom [1999].
} 
useful later in the paper, because it will mean that contracting on one dimension of effort will not distort effort with respect to other dimensions.

Combined with my specification of A2's value under different business formats, this cost specification implies that increasing the number of dimensions of effort $g_{1}$ or $g_{2}$ will lead to more managerial effort, summed over all activities. This particular set of assumptions is for modeling convenience, and is not crucial to the base model's results. One can produce the same comparative statics in an algebraically messier model where the vectors $\mathrm{e}_{1}$ and $\mathrm{e}_{2}$ have only one dimension apiece, and the marginal benefit of effort associated with these vectors is $g_{1}$ and $g_{2}$, respectively. One can therefore interpret variation in $\mathrm{g}_{1}$ or $\mathrm{g}_{2}$ either as differences in marginal productivities or in the number of managerial opportunities to affect assets' value.

Note that Victor and Paul are treated asymmetrically in the model in that only Paul makes effort decisions. None of the propositions generated from the model depend on this assumption; allowing Victor to take 'managerial' and 'entrepreneurial' actions that parallel Paul's extends the analysis but does not affect this paper's results. Details are available from the author upon request.

\section{III(ii). Timing and Assumptions}

The timing and assumptions are similar to Grossman and Hart [1986] and related papers. There are three stages. First, Victor and Paul negotiate over which format should be used for A2 and who should own it. I assume that they make efficient decisions with respect to affiliation and ownership. These decisions are renegotiable, and both parties realize this at the start. Second, Paul chooses $\mathrm{e}_{1}$ and $\mathrm{e}_{2}$ to maximize his own utility, conditional on the format and ownership decisions made in the first stage. Third, Victor and Paul observe $\mathrm{V}$ and $\mathrm{P}$ and negotiate over how the returns from $\mathrm{A} 2$ (either $\mathrm{V}$ or $\mathrm{P}$, depending on the format chosen) should be split. ${ }^{11}$ They may also negotiate over format and ownership at this point, although in the model format and ownership changes at this stage are not equilibrium outcomes.

I assume that asset ownership allows individuals to decide how assets are used in circumstances not covered by existing contracts. Further, I assume for simplicity that assets' use is completely non-contractible, and therefore that all control rights are residual. An important implication of these

\footnotetext{
${ }^{11}$ Alternatively, one could assume that Victor and Paul bargain over surplus (V-C or P-C) rather than revenues. I assume that they bargain over revenues because surplus includes effort costs, which are generally unobservable and hence unverifiable. It is natural to assume that Paul bears effort costs privately. In any case, this assumption does not affect the results. If Victor and Paul bargained over surplus, effort costs would affect Paul's inside and outside options equally, regardless of who owns A2. This would make Paul's marginal costs of effort the same as if he bore effort costs privately. Thus, neither Paul's decisions nor surplus under each organizational form depend on whether Victor and Paul bargain over revenues or surplus.
}

(C) Blackwell Publishing Ltd. 2004. 
assumptions is that Paul has the option of unilaterally operating A2 under his own format if and only if he owns A2. I also assume that V, P, and managerial effort choices $\left\{\mathrm{e}_{1}^{\mathrm{i}}\right\}$ and $\left\{\mathrm{e}_{2}^{\mathrm{i}}\right\}$ are not verifiable, and thus are non-contractible. Later I relax the assumption on the non-contractibility of effort.

Finally, I assume that the outcome of bargaining in the third stage is the Nash bargaining solution. Thus, how Victor and Paul divide surplus depends on their outside options. I normalize Victor's outside option to zero, regardless of whether he owns A2. ${ }^{12}$ I assume that Paul's outside option differs depending on whether he owns A2. If he owns A2, his outside option is to operate A2 under his own business format. Therefore, his outside option is equal to P. If Paul does not own A2, he does not have the option of operating A2 under his own business format. I will assume that his outside option is some constant (his wage in another job), which I will call W.

I solve the model by first examining Paul's decision under each organizational option, then comparing the surplus created under each option.

Case 1: Paul's format is used, Paul owns A2. (A2 is completely independent.) If Paul owns A2 and uses his own format, there is no trade and thus no bargaining between Victor and Paul. Paul appropriates the full value of his activities with respect to A2 if A2 is operated as a completely independent outlet. He therefore chooses $\mathrm{e}_{1}$ and $\mathrm{e}_{2}$ to maximize $\mathrm{P}-\mathrm{C}$, the value of his establishment net of effort costs. This equals:

$$
P-C=\sum_{i=1}^{g_{1}} e_{1}^{i}+\sum_{i=1}^{g_{2}} e_{2}^{i}-\sum_{i=1}^{g_{1}} \frac{1}{2}\left(e_{1}^{i}\right)^{2}-\sum_{i=1}^{g_{2}} \frac{1}{2}\left(e_{2}^{i}\right)^{2}
$$

Paul therefore chooses $e_{1}^{i}=1, e_{2}^{i}=1$. Plugging these choices into the expressions for $\mathrm{P}$ and $\mathrm{C}$, surplus equals $\left(\mathrm{g}_{1}+\mathrm{g}_{2}\right) / 2$.

Case 2: Paul's format is used, Victor owns A2.

Nash bargaining implies that Paul receives $(\mathrm{P}-\mathrm{W}) / 2+\mathrm{W}=(\mathrm{P}+\mathrm{W}) / 2 \mathrm{He}$ thus maximizes:

$$
\begin{aligned}
(P+W) / 2-C= & \frac{1}{2}\left(\sum_{i=1}^{g_{1}} e_{1}^{i}+\sum_{i=1}^{g_{2}} e_{2}^{i}+W\right)-\sum_{i=1}^{g_{1}} \frac{1}{2}\left(e_{1}^{i}\right)^{2} \\
& -\sum_{i=1}^{g_{2}} \frac{1}{2}\left(e_{2}^{i}\right)^{2}
\end{aligned}
$$

\footnotetext{
${ }^{12}$ This assumption is innocuous. Since the level of Victor's outside option does not affect Paul's marginal incentives, the results of the model would be the same if ownership of A2 improved Victor's outside option.
} 
and chooses $e_{1}^{i}=1 / 2, e_{2}^{i}=1 / 2$. This yields $3\left(g_{1}+g_{2}\right) / 8$, which is always less than the surplus in case 1. This case is therefore never relevant: if Paul's format is used, he should own A2. Giving Victor ownership provides no incentive benefits, and discourages surplus-increasing effort from Paul.

Case 3: Victor's format is used, Paul owns A2. (A2 is part of a chain of independently-owned outlets.)

Paul's share of the surplus is $(\mathrm{V}-\mathrm{P}) / 2+\mathrm{P}=(\mathrm{V}+\mathrm{P}) / 2$. He chooses $\mathrm{e}_{1}$ and $\mathrm{e}_{2}$ to maximize $(\mathrm{V}+\mathrm{P}) / 2-\mathrm{C}$, which is equal to:

$$
\frac{1}{2}\left(K+2 \sum_{i=1}^{g_{1}} e_{1}^{i}+\sum_{i=1}^{g_{2}} e_{2}^{i}\right)-\sum_{i=1}^{g_{1}} \frac{1}{2}\left(e_{1}^{i}\right)^{2}-\sum_{i=1}^{g_{2}} \frac{1}{2}\left(e_{2}^{i}\right)^{2}
$$

He therefore chooses $\mathrm{e}_{1}^{\mathrm{i}}=1, \mathrm{e}_{2}^{\mathrm{i}}=1 / 2$. The surplus from this case is $\mathrm{K}+1 / 2$ $\mathrm{g}_{1}-1 / 8 \mathrm{~g}_{2}$.

Case 4: Victor's format is used, Victor owns A2. (A2 is part of a commonlyowned chain.)

If Paul does not own $\mathrm{A} 2$, he maximizes $(\mathrm{V}+\mathrm{W}) / 2-\mathrm{C}$, which is equal to:

$$
\frac{1}{2}\left(K+\sum_{i=1}^{g_{1}} e_{1}^{i}+W\right)-\sum_{i=1}^{g_{1}} \frac{1}{2}\left(e_{1}^{i}\right)^{2}-\sum_{i=1}^{g_{2}} \frac{1}{2}\left(e_{2}^{i}\right)^{2}
$$

He therefore chooses $\mathrm{e}_{1}^{\mathrm{i}}=1 / 2, \mathrm{e}_{2}^{\mathrm{i}}=0$; surplus equals $\mathrm{K}+3 / 8 \mathrm{~g}_{1}$. Comparing cases 3 and $4, e_{1}$ and $e_{2}$ are higher when Paul owns A2 than when he does not. This is because he is better able to appropriate the returns from his efforts when he owns A2.

Table I summarizes the results to here and illuminates the trade-offs with respect to the three relevant organizational options.

If A2 is kept completely independent, Paul will choose high levels of both $\mathrm{e}_{1}$ and $\mathrm{e}_{2}$, and this is good. However, the parties forego the opportunity to use Victor's business format, which may be valuable.

If A2 is part of a chain of independent outlets, Paul has strong incentives with respect to $\mathrm{e}_{1}$ - management activities that increase A2's general value - and this is good. However, Paul also has fairly strong incentives to choose high levels of $e_{2}$. This is bad, given that Victor's format is being

TABLE I

EfFort and Surplus - All Effort Non-Contractible

\begin{tabular}{lll}
\hline & \multicolumn{1}{c}{ Effort } & \multicolumn{1}{c}{ Surplus } \\
\hline Completely independent & $\mathrm{e}_{1}^{\mathrm{i}}=1, \mathrm{e}_{2}^{\mathrm{i}}=1$ & $1 / 2 \mathrm{~g}_{1}+1 / 2 \mathrm{~g}_{2}$ \\
Chain, independently-owned & $\mathrm{e}_{1}^{1}=1, \mathrm{e}_{2}^{2}=1 / 2$ & $\mathrm{~K}+1 / 2 \mathrm{~g}_{1}-1 / 8 \mathrm{~g}_{2}$ \\
Chain, commonly owned & $\mathrm{e}_{1}^{1}=1 / 2, \mathrm{e}_{2}^{\mathrm{i}}=0$ & $\mathrm{~K}+3 / 8 \mathrm{~g}_{1}$ \\
\hline
\end{tabular}

(C) Blackwell Publishing Ltd. 2004. 
used - Paul's entrepreneurial activities are privately valuable because they help Paul appropriate a larger share of the returns from A2. However, they do not actually increase A2's value because they are never optimal to actually implement.

If A2 is part of a commonly-owned chain, Paul has weak incentives with respect to $\mathrm{e}_{1}$, and this is bad. But he also has weak incentives with respect to $\mathrm{e}_{2}$, which is good in light of the discussion above. Given that Victor's format is being used, it is better that Paul does not spend time on entrepreneurial activities.

This highlights the benefits and drawbacks of allowing Paul to own A2 under Victor's format. Ownership creates both good and bad incentives. It strengthens incentives both with respect to managerial activities $\left(\mathrm{e}_{1}\right)$ and entrepreneurial activities $\left(e_{2}\right)$. The former is always good; the latter is good only when Paul's format is used. This characterization of organizational trade-offs is consistent with managerial sentiment that while owning affiliated enterprises may weaken managerial incentives, it also allows for more control over these enterprises.

\section{III(iii). Results}

Figure 1 summarizes the results. The three regions in this figure correspond to situations where each of the three organizational choices are optimal. The optimal format and ownership combination depends on two ratios: $\mathrm{K} / \mathrm{g}_{2}$ and $\mathrm{g}_{1} / \mathrm{g}_{2}$.

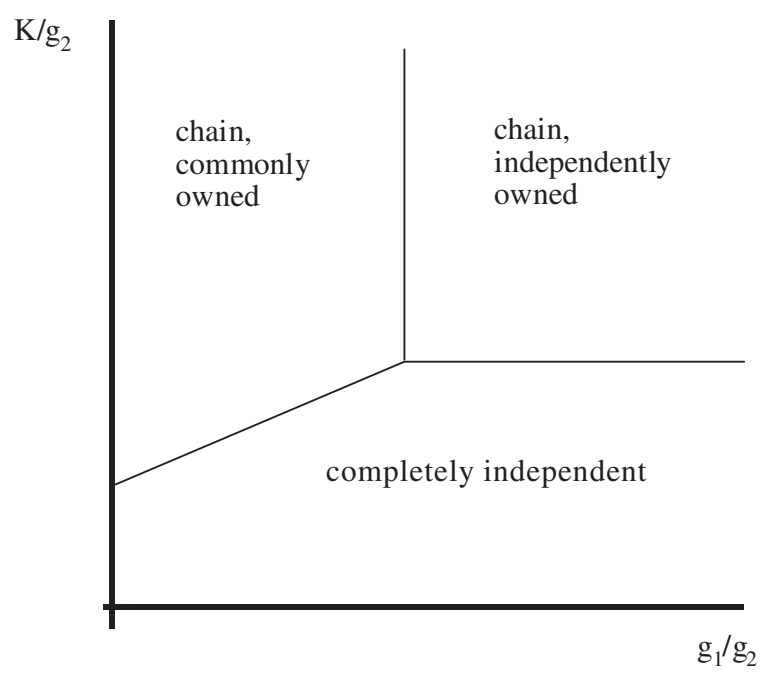

Figure 1

Business Formats and Ownership of Establishments 
Proposition 1. Chains are optimal when $\mathrm{K} / \mathrm{g}_{2}$ is high, but not otherwise.

The intuition behind this is simple. $\mathrm{K} / \mathrm{g}_{2}$ reflects whether the manager of an establishment has a comparative advantage in developing the establishment's business format. If $\mathrm{g}_{2}$ is low relative to $\mathrm{K}$, the manager does not have a comparative advantage - so becoming part of a chain is optimal. If $\mathrm{g}_{2}$ is high relative to $\mathrm{K}$, the manager has a comparative advantage - so being independent is optimal.

It is useful to note at this point why the line dividing 'chain, commonlyowned' and 'completely independent' is upward-sloping. The intuition is this. If $\mathrm{g}_{1}=0$, giving Paul management incentives offers no benefits, so if $\mathrm{g}_{2}>0$, the relevant chain option is 'commonly-owned chain.' The decision to operate A2 as part of a chain or not is made purely on the basis of whether Victor or Paul has a comparative advantage in developing the outlet's business format; that is, whether $\mathrm{K} / \mathrm{g}_{2}$ is greater than $1 / 2$. Increasing $\mathrm{g}_{1}$ slightly introduces an incentive cost to having A2 part of a chain; the slope of the dividing line reflects this incentive cost. If Victor's comparative advantage in developing the outlet's business format is very small, the comparative advantage will not outweigh the incentive cost and the outlet will remain completely independent.

Proposition 2. Establishments should be owned by their managers if $g_{1} / g_{2}$ is high, even when chains are optimal.

When $\mathrm{g}_{1} / \mathrm{g}_{2}$ is high, the benefits of having the manager own the establishment are high relative to the drawbacks. The benefit of managerial ownership is that it strengthens managers' incentives to do things that increase the establishment's value. If $\mathrm{g}_{1}$ is high, managers have many opportunities to increase the establishment's general value so the benefits of managerial ownership are high. The drawback associated with chains of independently-owned outlets is that ownership gives managers incentives to engage in unwanted entrepreneurial activities. But when $\mathrm{g}_{2}$ is low, managers have few opportunities to do so. The drawback to managerial ownership is therefore low.

Proposition 3. Industries are necessarily fragmented-that is, they necessarily consist of many independently-owned establishments - unless $\mathrm{K} / \mathrm{g}_{2}$ is high and $\mathrm{g}_{1} / \mathrm{g}_{2}$ is low, the upper-left region of Figure 1 .

The intuition behind this follows from propositions 1 and 2, which answer the question: why are commonly-owned chains not optimal in the other regions? When $\mathrm{K} / \mathrm{g}_{2}$ is low it is better to have the manager develop his or her own business format - so chains are not optimal. When $\mathrm{g}_{1} / \mathrm{g}_{2}$ is high, the benefits of having the manager own the establishment are high relative to the drawbacks, even when the store is part of a chain. 
One way to think about the upper left region is that it is where ownership incentives are unimportant for motivating managers. Motivating the manager to be entrepreneurial is unimportant, because using an existing business format is optimal ( $\mathrm{K}$ is high). Furthermore, motivating establishment management is relatively unimportant, because managers have few opportunities to do things that increase the establishment's general value ( $g_{1}$ is relatively low).

Managerial incentives are unimportant in most theories of industry structure. Such theories are implicitly considering situations in this region of Figure 1.

Ownership incentives are more important in the other regions. If the manager owns the establishment, he or she has a greater incentive both to increase the value of the establishment and to be entrepreneurial. If either of these classes of activities is valuable and managerial effort is noncontractible, it may be best for the manager to own the establishment. In such circumstances, industries will necessarily be fragmented (although one may observe independently owned firms that share business formats).

The non-contractibility assumption is important in the model above. I next extend the basic model by allowing managerial effort to be contractible to varying degrees. This will generate a set of comparative statics that relates variation in industrial organization to variation in the contracting environment. This is important because, as emphasized in Baker and Hubbard [2001], variation in the informational environment is sometimes more observable to applied researchers than variation in $\mathrm{K}$, $\mathrm{g}_{1}$, or $\mathrm{g}_{2}$.

\section{III(iv). Contractibility and Industrial Organization}

Partition the $g_{1}$ and $g_{2}$ dimensions of managerial effort so that $n_{1}$ and $n_{2}$ of them are non-contractible and $\mathrm{g}_{1}-\mathrm{n}_{1}$ and $\mathrm{g}_{2}-\mathrm{n}_{2}$ are contractible, respectively. Assume that effort decisions that are contractible are perfectly contractible, so that one can elicit first-best effort levels costlessly. V and P then become:

$$
\begin{aligned}
& V=K+\sum_{i=1}^{n_{1}} e_{1}^{i}+\sum_{i=n_{1}+1}^{g_{1}} e_{1}^{i} \\
& P=\sum_{i=1}^{n_{2}} e_{2}^{i}+\sum_{i=n_{2}+1}^{g_{2}} e_{2}^{i}+\sum_{i=1}^{n_{1}} e_{1}^{i}+\sum_{i=n_{1}+1}^{g_{1}} e_{1}^{i}
\end{aligned}
$$

Table II summarizes the results from solving the model under this new set of assumptions.

Under the 'completely independent' option, nothing changes. Paul chooses first best levels of $\mathrm{e}_{1}$ and $\mathrm{e}_{2}$, regardless of the contracting environment. Effort and surplus are the same as before. 
TABLE II

EfFort and Surplus - Effort Partly Contractible

\begin{tabular}{lccc}
\hline & Contractible Effort & Non-Contractible Effort & Surplus \\
\hline Completely independent & $\mathrm{e}_{1}^{\mathrm{i}}=1, \mathrm{e}_{2}^{\mathrm{i}}=1$ & $\mathrm{e}_{1}^{\mathrm{i}}=1, \mathrm{e}_{2}^{\mathrm{i}}=1$ & $1 / 2 \mathrm{~g}_{1}+1 / 2 \mathrm{~g}_{2}$ \\
Chain, independently-owned & $\mathrm{e}_{1}^{\mathrm{i}}=1, \mathrm{e}_{2}^{1}=0$ & $\mathrm{e}_{1}^{1}=1, \mathrm{e}_{2}^{\mathrm{i}}=1 / 2$ & $\mathrm{~K}+1 / 2 \mathrm{~g}_{1}-\mu_{2} \mathrm{~g}_{2} / 8$ \\
Chain, commonly owned & $\mathrm{e}_{1}^{1}=1, \mathrm{e}_{2}^{1}=0$ & $\mathrm{e}_{1}^{1}=1 / 2, \mathrm{e}_{2}^{\mathrm{i}}=0$ & $\mathrm{~K}+\left(1 / 2-\mu_{1} / 8\right) \mathrm{g}_{1}$ \\
\hline
\end{tabular}

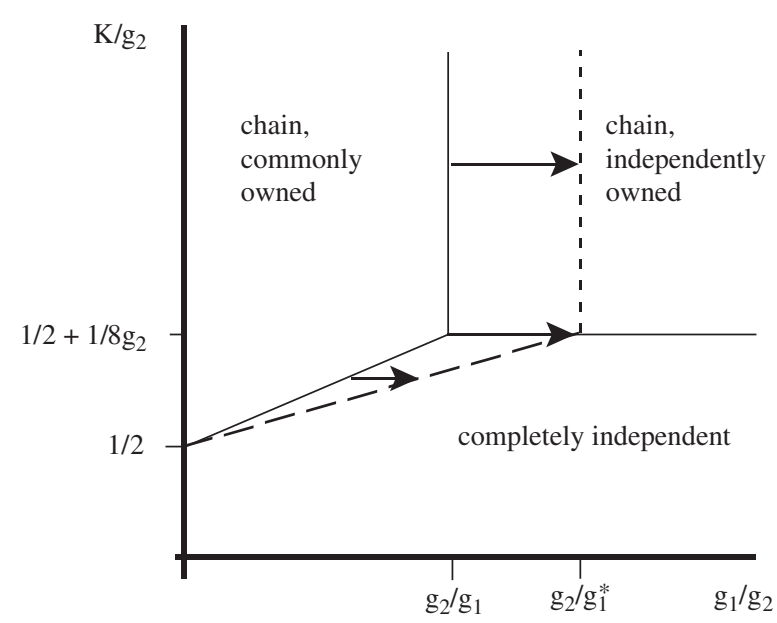

Figure 2

Increasing the Contractibility of $\mathrm{e}_{1}$

Under the 'independent chain' option, the contractible decisions are set at first-best given the format, which is $\mathrm{e}_{1}^{\mathrm{i}}=1, \mathrm{e}_{2}^{\mathrm{i}}=0$. Non-contractible decisions are as before, $e_{1}^{i}=1, e_{2}^{i}=1 / 2$. Surplus is $\mathrm{K}+\mathrm{g}_{1} / 2-\mu_{2} \mathrm{~g}_{2} / 8$, where $\mu_{2}=n_{2} / g_{2}$ is the fraction of entrepreneurial decisions that are noncontractible.

If A2 operates as part of a commonly-owned chain, the contractible decisions are once again set at $\mathrm{e}_{1}^{\mathrm{i}}=1, \mathrm{e}_{2}^{\mathrm{i}}=0$. The non-contractible decisions are $\mathrm{e}_{1}^{\mathrm{i}}=1, \mathrm{e}_{2}^{\mathrm{i}}=1 / 2$, and total value is $\mathrm{K}+\mathrm{g}_{1}\left(1 / 2-\mu_{1} / 8\right)$, where $\mu_{1}=\mathrm{n}_{1} / \mathrm{g}_{1}$ is the fraction of non-entrepreneurial decisions that are non-contractible.

Figures 2 and 3 depict how the organizational options depend on $\mu_{1}$ and $\mu_{2}$, the extent to which managerial decisions are contractible. I next discuss a series of propositions using these figures.

Figure 2 shows the effect of decreasing $\mu_{1}$, the fraction of managerial effort that is non-contractible. Decreasing $\mu_{1}$ shifts the vertical line separating the two chain regions to the right and flattens the diagonal that separates commonly-owned chain from completely independent.

Proposition 4. Increases in the contractibility of establishment management should shift outlets from completely independent and independently-owned 


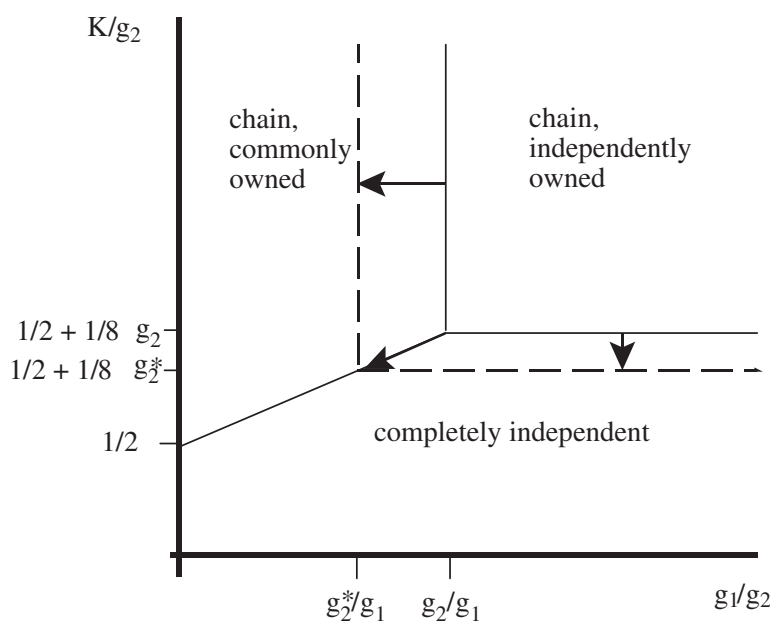

Figure 3

Increasing the Contractibility of $\mathrm{e}_{2}$

chains to commonly-owned chains. Thus, such increases should make industries more concentrated and lead to more chains.

Decreases in $\mu_{1}$ affect two margins. They shift outlets that are part of chains from independently-owned to commonly-owned by eliminating an advantage of independent ownership. If establishment management becomes contractible, then one can elicit first-best effort levels with a contract and discourage unwanted entrepreneurial effort by denying the manager ownership.

Decreasing $\mu_{1}$ also shifts completely independent outlets to commonlyowned chains - some outlets change both ownership and affiliation. The intuition for this follows the discussion under Proposition 1. Starting from $\mathrm{g}_{1}=0$, increasing $\mathrm{g}_{1}$ introduces an incentive cost to operating $\mathrm{A} 2$ as part of a chain; thus, some outlets will remain independent if the outlet manager's comparative disadvantage in developing the outlet's format is sufficiently small. Decreasing $\mu_{1}$ diminishes the incentive cost of becoming part of a chain relative to 'completely independent,' and thus more outlets become part of chains.

It is important for empirical testing to recognize two additional results from this diagram - where the model predicts that changing $\mu_{1}$ should have no effect.

Proposition 5. Changes in $\mu_{1}$ should not affect industrial organization if $\mathrm{K} / \mathrm{g}_{2}$ is low.

Proposition 6. Changes in $\mu_{1}$ should not lead outlets to move from completely independent to independently-owned chain, or vice-versa. 
Note that the organizational effect of decreasing $\mu_{1}$ is exactly the same as decreasing $\mathrm{g}_{1}$ : increasing the contractibility of establishment management has the same impact as decreasing the marginal productivity of such effort. Below I show that this equivalence result does not hold for $\mu_{2}$ and $g_{2}$.

Figure 3 shows the effect of decreasing $\mu_{2}$, the fraction of entrepreneurial effort that is non-contractible. Decreasing $\mu_{2}$ shifts the borders of "chain, independently-owned' down and to the left.

Proposition 7. Increases in the contractibility of entrepreneurial effort should shift outlets from commonly-owned chains and completely independent to independently-owned chains. Thus, increases in the contractibility of such effort should make industries less concentrated but lead to more chains.

Making $\mathrm{e}_{2}$ more contractible reduces the drawbacks associated with 'independently-owned chain' by allowing parties to discourage unwanted entrepreneurial effort with contracts. Within a chain, this allows firms to achieve the benefits of giving managers ownership incentives at a lower incentive cost. It will also lead to fewer independent outlets and thus more chains in general. If $\mathrm{g}_{1} / \mathrm{g}_{2}$ is high, the relevant chain option involves independent ownership. The incentive costs associated with chains diminish in this region as entrepreneurial effort becomes more contractible.

As above, there are two additional propositions related to where changes in $\mu_{2}$ should have no effect.

Proposition 8. Changes in $\mu_{2}$ should have no impact if $\mathrm{K} / \mathrm{g}_{2}$ is low.

Proposition 9. Changes in $\mu_{2}$ should not lead outlets to move from completely independent to commonly-owned chain, or vice-versa.

As noted above, the comparative statics of $g_{2}$ are different than those of $\mu_{2}$. (See Figure 4.) This is because changing $g_{2}$, Paul's entrepreneurial opportunities, has two effects. Increasing $\mathrm{g}_{2}$ raises the incentive costs associated with the independently-owned chain option, thereby pushing outlets away from this option and toward the others. This effect is the same as when one increases $\mu_{2}$. The other effect is different: increasing $g_{2}$ also raises the comparative advantage of using Paul's business format. This can shift outlets from commonly-owned chain to completely independent, something that the model predicts will not happen with a decrease in $\mu_{2}$.

Finally, note that as either $\mu_{1}$ or $\mu_{2}$ approaches zero-that is, as either class of effort becomes completely contractible - the border separating the chain options from the completely independent option approaches the horizontal line $\mathrm{K} / \mathrm{g}_{2}=1 / 2$. Thus, contractual incompleteness leads to fewer 


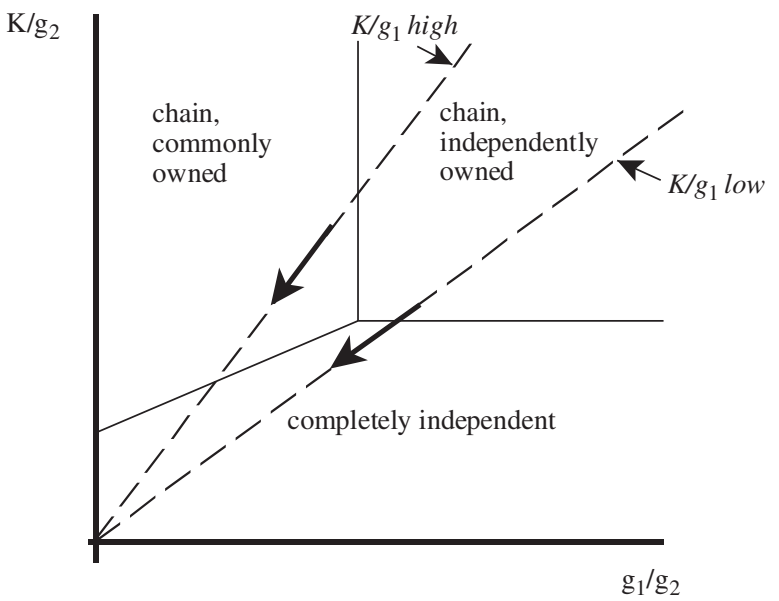

Figure 4

Increasing $\mathrm{g}_{2}$

chains than first-best, and therefore affects the concentration of brands as well as firms.

While the model analyzes the effects of informational changes that make effort decisions - managerial inputs - more contractible, the basic analysis can extend to situations where informational changes make managerial outputs more contractible. The model is constructed so that improvements in performance incentives with respect to a particular activity diminishes the incentive importance of control rights with respect to the activity: they allow individuals to replicate control rights' good incentive features and/or undo their bad ones. What is important is the economic relationship between performance incentives and control rights, not whether performance incentives are based on input or output-based measures. As a consequence, the discussion below of relationships between variation in contractibility and organizational form refers to differences in the efficiency of performance incentives in general, and does not distinguish between input and output-based performance measures. ${ }^{13}$

\footnotetext{
${ }^{13}$ It is easy to construct models where the relationship between performance incentives and control rights is different from that in the model above. In these, the distinction between input and output based incentives can matter. For example, improving the contractibility of an activity can enhance rather than diminish the importance of how control rights are allocated in more complicated multitasking models in which individuals make meaningful effort allocation decisions (Holmstrom and Milgrom [1994]). See Prendergast [2002] for an analysis of the tradeoffs between input- and output-based performance incentives in contexts where the optimal allocation of individuals' effort is unknown ex ante.
} 


\section{DISCUSSION AND EXAMPLES}

This section of the paper discusses a series of examples that depict how the various factors highlighted in the model affect the structure of different industries. Some of these examples come from the existing empirical literature on organizational form, including several that analyze how firms' boundaries reflect the importance $\left(\mathrm{g}_{1}\right)$ or contractibility $\left(\mu_{1}\right)$ of managerial decisions. The account below shows how the simple canonical model outlined above connects results in this literature-which highlight the incentive benefits of managerial ownership - to each other and to other, anecdotal evidence. In contrast, while the idea that limiting rent-seeking is an important organizational objective has been in the literature for some time (Milgrom and Roberts [1990]), there has been little work on how ownership rights reflect the marginal productivity $\left(\mathrm{g}_{2}\right)$ or contractibility $\left(\mu_{2}\right)$ of entrepreneurial actions. The trucking and fast food examples below suggest that these factors affect industry structure in some industries; additional research is needed to provide systematic evidence regarding the range of these factors' importance.

\section{IV(i). Manufacturing and Cost Accounting}

In the introduction, I reported that service industries tend to be very fragmented. In an earlier era, manufacturing industries were extremely fragmented as well. Before the mid-1800s, there were virtually no large firms in the U.S. No single establishment had more than 250 workers, and nearly all firms were single-establishment enterprises. By the end of the $19^{\text {th }}$ century, however, there were many large multi-establishment firms. Chandler [1977] investigates the sudden growth of firms during this period, and attributes it to a set of complementary innovations. Some of these were technological improvements that increased the efficiency of mass production relative to craft production. Others were improvements in transportation - the railroad - that enabled firms to distribute goods over wider areas. Interestingly, Chandler also cites innovations in business practices - particularly the development of cost accounting - that, among other things, made particular dimensions of managerial effort more contractible. In the words of an important innovator in cost accounting at the time, Daniel C. McCallum, new cost accounting methods were intended to help identify 'officers who conduct their business with the greatest economy, and...by comparison of the details, direct attention to those matters in which sufficient economy is not practiced.' (Chandler [1977], p. 115-6) These methods were an improvement over relying only on financial accounting data, which provided only broad, imprecise measures of individual establishment managers' performance. By lowering $\mu_{1}$, cost accounting innovations played a role in the defragmentation of many manufacturing industries. 
IV(ii). Banks

Banks supply many types of financial services, some of which involve managerial discretion. For example, consider the decision whether to grant a small business a loan. Bank managers use objective factors - such as the entrepreneur's credit history-in making such decisions. However, subjective factors can be informative as well; for example, a manager may be able to augment information from objective factors from a meeting with the entrepreneur, learning (sometimes difficult to quantify) local economic trends, and so on. It is difficult to use performance incentives to motivate managers to obtain information and make appropriate decisions on loan applications. For example, basing managers' bonuses on default rates would encourage them to only accept loans from 'sure bets.' Furthermore, whether entrepreneurs default on loans may only be known long after bank managers have left the bank for other positions. These and other factors impede the use of performance incentives.

Motivating bank managers to garner and process subjective information about borrowers' prospects is important - that is, $g_{1}$ is high - when loans are to businesses whose prospects are difficult to quantify. Furthermore, $\mu_{1}$ is high because it is difficult to motivate bank managers to do so contractually. One would therefore predict that manager-owned establishments should tend to handle a disproportionate share of small business loans. Recent research is consistent with this prediction. Brickley, Linck, and Smith [2002] find that ownership patterns in bank offices reflect the composition of demand. In rural locations, where commercial loans tend to be to small businesses and farmers, bank offices tend to be owned by their managers. In cities, where commercial loans tend to be to large businesses, bank offices tend not to be owned by their managers - rather, they are part of a large chain of commonly-owned branches. These authors also find that, within cities, banks' loan portfolios vary with their organizational form. The loan portfolios of independently-owned offices tend to be disproportionately comprised of consumer and agricultural loans, while those of offices that are part of commonly-owned chains tend to be disproportionately comprised of commercial loans. Consistent with Figure 1 , establishments tend to be independently owned in segments of banking where $g_{1}$ and $\mu_{1}$ are high, but commonly owned in segments where $g_{1}$ is low. ${ }^{14}$

A similar logic may explain why lenders of venture capital, who operate in a segment where there are few objective measures of lenders' prospects and

\footnotetext{
${ }^{14}$ Peterson and Rajan [2002] show that the average distance between small businesses and their lenders has increased over time, and attribute this to informational and communication improvements that have diminished local banks' comparative advantage in assessing credit risks. Similar themes appear in Lamoreaux's [1994] account of lending practices in $19^{\text {th }}$ century New England.
} 
thus high returns to collecting and processing subjective information, are generally independently-owned enterprises.

Banking also provides a good example of why affiliation need not imply common ownership, and therefore why increases in the value of chain operation need not lead industries to become heavily concentrated. Affiliations among individual bank offices are valuable for many reasons. For example, they can facilitate check-clearing and other back-office processes and help pool loan portfolios, thereby lowering risk. Affiliations can also raise consumers' willingness to pay for the bank's services, for example, by allowing customers of one office to obtain cash from another office's ATM. K is thus fairly high in banking, and has increased with the emergence of ATMs. Nevertheless, a high and increasing $\mathrm{K}$ has not led to the extinction of independently-owned banks. Increases in K cause establishments to move up in Figure 1, thereby causing stand-alone offices to either become part of commonly owned chains (i.e., converted to being a branch of a large bank) or become part of a network of independently-owned banks. ATM networks and 'bankers' banks' - institutions that provide transaction processing and loan pooling services to independently-owned member banks - allow independent banks to garner the benefits of affiliation in a way that does not involve common ownership.

\section{IV(iii). Service-Intensive Retail Contexts}

A similar logic applies when contrasting retail segments with different serviceintensities. Returning to the example mentioned in the introduction, some segments of hardware and building supply retail provide customized services and advice as well as products. For example, many hardware stores provide locksmith services, and give customers personalized advice on how to complete their particular home repair. ${ }^{15}$ As one would expect, industry structure is much more fragmented in this service-intensive segment than in segments that are less service-intensive. Establishments in this segment are rarely part of commonly-owned chains. Home Depot's recent expansion into smaller-store formats follows this organizational logic; while its 'Villager's' format stores have more convenient locations than their regular stores, they do not supply the highly-customized services that hardware stores currently do. ${ }^{16}$

This example parallels Shepard's [1993] study of organizational form in gasoline retailing. Gasoline stations are affiliated through the brand name of the gasoline they sell, and are either commonly owned (usually by a refiner) or independently owned (usually by their manager). Shepard finds that

\footnotetext{
${ }^{15}$ The distinction between customized and non-customized services and advice is important here. Individuals at Home Depot stores do provide project advice, but this advice is often not personalized (for example, through home improvement classes).

${ }^{16}$ Garbarine [1999], Hagerty [1999].

(C) Blackwell Publishing Ltd. 2004.
} 
whether refiners own stations depends on the ancillary services they offer. Stations that have convenience stores tend to be commonly-owned; stations that have repair shops tend to be independently owned. Shepard argues that this reflects differences in the contractibility of managerial effort between the ancillary services: it is easy to evaluate convenience store managers, thus motivating them with performance incentives works well. But it is hard to do so with auto repairers. Like in the service-intensive segments of hardware and building supply retail, auto repairers tend to have many opportunities to increase establishments' value, and their effort with respect to these opportunities tends to be difficult to evaluate because it can be hard to find good performance measures. This makes it desirable for managers of these establishments to be owners, and implies that these service-intensive segments tend to be more fragmented than less service-intensive segments.

\section{IV(iv). Video Stores}

The evolution of the video rental industry offers another nice example. ${ }^{17}$ Video rental stores began to appear in the early 1980s in most parts of the U.S. At the time, nearly all were small, independently-owned outlets that had no chain affiliation. A few outlets were part of small chains such as Video Connection and Video Station, but even these were independentlyowned franchises. ${ }^{18}$ Since then, the organization of the video rental industry has become far less fragmented, especially during the mid-1990s. Between 1992 and 1997, single-establishment firms' share of storefronts fell from $69 \%$ to $54 \%$, while the share of establishments part of firms with ten or more establishments increased from $13 \%$ to $34 \% .{ }^{19}$ Why are there commonlyowned chains now, but not earlier?

Video rental tastes differ sharply across local markets, even at the neighborhood level within metropolitan areas. It is important that stores are stocked with movies that appeal to local customers' tastes. Traditionally, store managers have had a comparative advantage in assessing local customers' tastes - for example, they receive feedback from customers when they take out and return movies. Managers' stocking decisions are difficult to evaluate using objective measures (how much of a store's current and future sales are due to good stocking decisions?); thus, performance incentives would generally not work very well in motivating managers to expend effort toward learning local tastes and making good inventory decisions. $g_{1}$ and $\mu_{1}$ have traditionally been high, favoring independent ownership and leading to a fragmented industry.

\footnotetext{
${ }^{17}$ This example evolved from discussions with Judy Chevalier. See Mortimer [2001] for a study of the welfare gains from contractual innovations in this industry.

${ }_{18}^{18}$ Paikert [1982].

${ }^{19}$ Bureau of the Census [1995b, 2000].
} 
During the mid-to-late 1980s, information technology in video stores became more sophisticated. Bar-coders and scanners that could capture transaction level data electronically began to diffuse in the industry. Capturing detailed point-of-sales data enabled firms to analyze store-level sales and inventory patterns centrally, and reduced store managers' comparative advantage in learning local tastes. Store-level stocking decisions now can be made just as well (or better) by a central office as by a store manager. In the model, moving local market analysis and purchasing decisions away from managers would lower $\mathrm{g}_{1}$, and move outlets to the left in Figure 1; IT-related changes in managers' jobs should lead to more commonly-owned chains and a more concentrated industry.

In fact, accounts from the trade press suggest that the adoption of inventory tracking and analysis systems and the emergence of large commonly owned chains are related. The two chains that are cited by the trade press in the late-1980s as the most sophisticated users of inventory management technologies, Blockbuster and the now-defunct Erol's, were also among the first chains in which stores were not owned by their managers. ${ }^{20}$ The large chains that have emerged since then, such as Hollywood Video, Video Update, and Movie Gallery all have sophisticated centralized inventory tracking systems, and operate chains of hundreds of commonly owned outlets. These companies' securities filings commonly cite their use of point-of-sales technologies as critical to their business, claiming that they are crucial to store-level purchasing and inventory decisions. ${ }^{21}$ Consistent with the theory, the diffusion of these technologies appears to have strongly contributed to the rapid emergence of commonly owned chains and thus to the defragmentation of the industry. ${ }^{22}$

\section{IV(v). Trucking}

Baker and Hubbard [2002] examine similar issues in the context of trucking. The question they examine is whether drivers own the trucks they operate. Affiliations arise across drivers and trucks through common dispatch, and are valuable when dispatchers have a comparative advantage relative to drivers in finding hauls for the truck. The advantage of using owneroperators is that drivers take better care of trucks when they own them. Driver ownership of trucks is costly within affiliations because ownership encourages them to engage in unwanted entrepreneurial activities. Identifying hauls other than the one their dispatcher wants them to accept

\footnotetext{
${ }^{20}$ Keefe [1988], Chain Store Age Executive [1990], Chakravarty [1988], Wiener [1991].

${ }^{21}$ See, for example, Movie Gallery's 2000 10-K.

${ }^{22}$ Other factors may have increased $\mathrm{K}$ during this time, thereby encouraging the formation of chains. So the emergence of Blockbuster may reflect two factors: an increase in the effectiveness of advertising - which led to the formation of chains - and an increase in the contractibility of managers' decisions - that led chains to be commonly owned.
}

(C) Blackwell Publishing Ltd. 2004. 
can give them leverage in negotiating with dispatchers, particularly in circumstances where they are away from their base and are making arrangements for the truck's 'backhaul' (return trip).

Baker and Hubbard show that the introduction of on-board computers - technologies that let firms monitor how drivers operate trucks - has led to less driver ownership of trucks. Consistent with Figure 2, decreases in $\mu_{1}$ have led affiliations to involve less asset ownership by their users, and thus have led the industry to become somewhat less fragmented. Baker and Hubbard also provide evidence that ownership patterns, and hence trucking firms' boundaries, reflect variation in $\mathrm{g}_{2}$. They find that drivers own trucks more when hauls use trailers for which demands are unidirectional (such as logging trailers) than bidirectional (such as non-refrigerated vans). This provides evidence that part of the cost of driver ownership is that it encourages rent-seeking behavior. Ownership provides no incentive to find alternative 'backhauls' (return trips) when hauls use trailers such as logging trailers because there is no demand for 'backhauls' that would use such equipment: $g_{2}$ is very low. In contrast, $g_{2}$ is higher when hauls use trailers for which demands are bidirectional; drivers can find 'backhauls' for the truck other than the one their dispatcher wants them to take.

When $\mathrm{g}_{2}$ is high, this leads organizational arrangements in trucking to be 'chain, commonly owned'; lower levels of $\mathrm{g}_{2}$ lead them to be 'chain, independently owned.' The latter form has become less valuable, and thus less prevalent, as $\mu_{1}$ has increased.

\section{IV(vi). Uniformity and Industry Structure in Franchising ${ }^{23}$}

Franchising began shortly before the end of the $19^{\text {th }}$ century. Early franchises were for the rights for the sale or distribution of manufactured items such as sewing machines, automobiles, and gasoline. Franchise agreements generally provided franchisees the exclusive right to sell or distribute goods within well-defined territories. Territories were often very wide, sometimes encompassing entire states. These agreements allocated few ownership rights to franchisers. For example, franchisers generally had no control rights over any of the land or equipment used by the franchisee, and franchisees were usually free to develop their territories as they wished. Most franchisees at this time were sellers of manufactured goods, and most were part of 'independently owned chains.'

Franchising became much more common after World War II, as various firms began to employ franchise arrangements in other contexts, such as restaurants; examples include Dairy Queen, Big Boy, and of course, McDonald's. At first, these firms applied the same organizational form as

\footnotetext{
${ }^{23}$ Much of this section draws from Love's [1995] outstanding account of McDonald's and other franchisers.
}

(C) Blackwell Publishing Ltd. 2004. 
their predecessors, but found that they had major problems motivating franchisees to conform to agreements regarding business practices. Although franchisers could stipulate operating procedures in great detail as part of franchise agreements, courts viewed franchisees as independent businessmen and were unwilling to enforce provisions that constrained how they ran their business. This was a particular problem at McDonald's, where cross-outlet uniformity in virtually all aspects of operations was considered an important source of the business format's value. Early franchisees departed from the format in various ways, including purchasing inputs from non-approved suppliers, adding menu items, customizing food for individual customers (e.g., grilling onions), and changing operating procedures to suit their tastes. These departures were a form of free-riding when they hurt other outlets within the chain.

McDonald's addressed this problem by departing from existing franchising practices in two ways. First, it retained the right to determine whether franchisees could open additional outlets, even when franchisees were granted exclusive territories. Although it could not easily terminate a nonconforming franchise through court action, it could deny its expansion. Second, after it had sold its first few franchises, it began to hold control rights over the land and buildings in which franchises operated. The following account explains the organizational logic:

'Kroc and Sonneborn [Kroc's partner at the time] believed that control of the real estate also gave McDonald's the type of control over the franchisee that it wanted but could not get from a franchise arrangement. Dozens of court cases have since defined the rights of the franchisee and the powers of the franchiser, but franchising was not well recognized in law in the 1950s. What was to prevent a franchisee from taking down the McDonald's sign, changing the restaurant name, and withholding his royalty fee? What power did McDonald's have to discipline the recalcitrants in its operator community who did not want to abide by the rules on menu or operating standards? In a battle with such malcontents, Sonneborn said, 'I never thought the franchise contract was worth the paper it was written on...'

'Such was not the case with a lease. It was a time-honored legal document, and McDonald's quickly made compliance with its operating standards one of the requirements of the lease. 'We connected the lease to the franchise so that any violation of the franchise could create termination of the lease,' Sonneborn explained...

'Sonneborn's thinking was extremely appealing to Ray Kroc in the mid1950s when he was having such difficulty with.... [early] franchisees, most of whom owned their units and leased the property from landowners...' I have finally found the way that will put every single McDonald's we open 
under our complete control,' an excited Kroc reported ... in early 1957, as he explained Sonneborn's plan., ${ }^{24}$

McDonald's innovation reallocated residual control rights in a way that moved its franchised outlets from 'independently-owned chain' to 'commonlyowned chain.' The company's practice of retaining control rights over the establishment itself was quickly copied by many other franchised chains, including Southland's 7-11 stores, and more recently, Subway. ${ }^{25}$

When uniformity is an important element of a business format, outlet managers have a stream of opportunities to depart from this, effectively creating a new business format based on the original. Thus, $g_{2}$ tends to be high. $\mu_{2}$ tends to be high as well when courts tend not to enforce contractual provisions regarding managers' 'entrepreneurial activities.' In light of the model, it is thus not surprising that in circumstances like McDonald's, where uniformity is important, the owner of the format also owns individual establishments' physical assets. It is also not surprising that manager ownership has been problematic when uniformity is valuable but difficult to motivate contractually.

In several of the examples above, the difficulty of motivating $\mathrm{e}_{1}$ contractually led industries to be necessarily fragmented. Technological change that mitigated this contracting problem led the trucking and video rental industries to become more concentrated. Here, the situation is reversed. Contractual difficulties led chains to be commonly-owned where uniformity is important, and thus made the industry more concentrated than it otherwise would be. It follows that contractual improvements in fast food due to legal or technological changes in the contractibility of entrepreneurial activities would lead the industry to become more fragmented: managers would own their establishments more.

The general lesson is that contractual difficulties can led industries to be more or less fragmented, depending on the nature of the difficulties.

\section{CONCLUSION}

Different strains of the industrial organization literature examine the configuration of affiliations and ownership within industries. This paper presents a theory that examines these jointly, and demonstrates how affiliation and ownership patterns relate to the characteristics of managers' jobs and the contracting environment. I show how and why contractual incompleteness can lead industries to be necessarily fragmented. I also show

\footnotetext{
${ }^{24}$ Love [1995], p. 156-7.

${ }^{25}$ Thus, using the control-rights-based definition of ownership used in this paper, whether franchise outlets should be considered part of 'independently owned chains' or 'commonly owned chains' depends on whether franchisors retain control rights over assets essential to production, not on the allocation of residual claims.
} 
that while improvements in the contracting environment tend generally to lead to more chains, they can lead industry structure to be more or less concentrated depending on what becomes more contractible. Finally, I present a series of case examples from historical accounts, the existing empirical literature, and the trade press that show how the relationships depicted in the model appear in the real world.

The theory and evidence in this paper are foundational. On the theoretical front, the canonical model can be extended in various ways. One can relax assumptions to allow multiple individuals' decisions to affect the gains from trade, permit individuals' effort decisions to be related across dimensions, or move away from single-manager establishments. This would allow one to analyze how organizational trade-offs involving appropriation, effort allocation, and delegation examined by other authors interact with those examined here. On the empirical front, the next steps are clear. The case narratives in this paper are consistent with several of the model's propositions. But they are more suggestive than conclusive. Additional research is needed to test the model's propositions more rigorously, using systematic data. Such evidence would help determine whether the basic trade-offs examined herein are systematically important, improve our understanding of fragmentation, and provide empirical links between two major strains of the industrial organization literature.

\section{REFERENCES}

Bain, J. S., 1956, Barriers to New Competition (Harvard University Press, Cambridge).

Baker, G. P. and Hubbard, T. N., 2002, 'Contractibility and Asset Ownership: On-Board Computers and Governance in U.S. Trucking," working paper, University of Chicago Graduate School of Business.

Baker, G. P. and Hubbard, T. N., 2001, 'Empirical Strategies in Contract Economics: Information and the Boundary of the Firm,' American Economic Review, 91, pp. 189-194.

Brickley, J. A., Linck, J. S. and Smith, C. W., 2002, 'Boundaries of the Firm: Evidence from the Banking Industry,' Journal of Financial Economics, forthcoming.

Bureau of the Census, (1995a), 1992 Census of Service Industries: Establishment and Firm Size (G.P.O., Washington).

Bureau of the Census, (1995b), 1992 Census of Retail Industries: Establishment and Firm Size (G.P.O., Washington).

Bureau of the Census, 2000, 1997 Economic Census. Real Estate and Rental and Leasing: Establishment and Firm Size (G.P.O., Washington).

Chandler, A. E., 1977, The Visible Hand: The Managerial Revolution in American Business (Belknap, Cambridge).

Chain Store Age Executive, 1990, 'Blockbuster POS Focuses on Three Goals,' 66:1, p. 88.

Chakravaty, S., 1988, 'Give 'em Variety,' Forbes, 141:10, p. 54.

Dixit, A. K. and Stiglitz, J. E., 1977, 'Monopolistic Competition and Optimum Product Diversity,' American Economic Review, 67, p. 297-308.

Garbarine, R., 1999, 'Sensing Room For Growth, Home Depot Looks Small,' New York Times, 149:14NJ, 2. 
Grossman, S. and Hart, O., 1986, 'The Costs and Benefits of Ownership: A Theory of Vertical and Lateral Integration,' Journal of Political Economy, 94, pp. 691-719.

Hagerty, J. R., 1999, 'Home Depot Ups the Ante, Targeting Smaller Rivals,' Wall Street Journal, 233:16, p. 1.

Holmstrom, B., 1999, 'The Firm as a Subeconomy,' Journal of Law, Economics, and Organization, 15, pp. 74-102.

Holmstrom, B. and Milgrom, P., 1991, 'Multitask Principal-Agent Analyses: Incentive Contracts, Asset Ownership, and Job Design,' Journal of Law, Economics, and Organization, 7, pp. 24-52.

Holmstrom, B. and Milgrom, P., 1994, 'The Firm as an Incentive System,' American Economic Review, 84, pp. 972-91.

Lamoreaux, N. R., 1994, Insider Lending: Banks, Personal Connections, and Economic Development in Industrial New England (Cambridge University Press, Cambridge).

Love, J. F., 1995, McDonalds: Behind the Arches (Bantam, New York).

Keefe, P., 1988, 'Video Rental King Loads in Automation,' Computerworld, 22:7, p. 47.

Maness, R., 1996, 'Incomplete Contracts and the Choice between Vertical Integration and Franchising,' Journal of Law, Economics, and Organization, 31, p. 101-115.

Milgrom, P. and Roberts, J., 1990, 'Bargaining Costs, Influence Costs, and the Organization of Economic Activity,' in Perspectives on Positive Political Economy Alt, J. and Shepsle, K. eds., (Cambridge University Press, Cambridge).

Mortimer, J. H., 2001, 'The Effects of Revenue-Sharing on Welfare in VerticallySeparated Markets: Evidence from the Video Rental Industry,' working paper, Harvard University.

Paikert, C., 1982, 'Tuning In to the Home Video Explosion,' Chain Store Age Executive, 586, pp. 33-36.

Peterson, M. A. and Rajan, R. G., 2002, 'Does Distance Still Matter? The Information Revolution in Small Business Lending,' Journal of Finance, 57, pp. 2533-2570.

Prendergast, C., 2002, 'The Tenuous Trade-Off Between Risk and Incentives,' Journal of Political Economy, 110, pp. 1071-1102.

Salop, S. C., 1979, 'Monopolistic Competition with Outside Goods,' Bell Journal of Economics, 10, pp. 141-156.

Shepard, A., 1993, 'Contractual Form, Retail Price, and Asset Characteristics in Gasoline Retailing,' Rand Journal of Economics, 24, pp. 58-77.

Spence, A. M., 1976, 'Product Selection, Fixed Costs, and Monopolistic Competition,' Review of Economic Studies, 66, pp. 407-14.

Sutton, J., 1991, Sunk Costs and Market Structure (MIT Press, Cambridge).

Wiener, T., 1991, 'The Video King and I,' Washington Post, 114:256, p. WMAG16. 